\title{
Research on Ideological and Political Education Reform in Higher Vocational Colleges Oriented to Entrepreneurship Education
}

\author{
Ping Ni \\ Department of Telecom Engineering, Liaoning Railway Vocational and Technical College, Jinzhou, 121000, \\ China
}

305254185@qq.com

Keywords: entrepreneurship education; higher vocational ideological and political course; teaching reform

\begin{abstract}
With the rapid transformation of society, education system reform in domestic has achieved great development, research on ideological and political education reform in higher vocational colleges oriented to entrepreneurship education has become increasingly popular and important, but is still faced with some problems in the process of reform, causing the domestic teaching level has not been much improved. Based on that fact, this article is going to discuss in detail, hoping the students can learn more things from the education reform process, which is also the ultimate goal of education research and the core task.
\end{abstract}

\section{Introduction}

The traditional examination-oriented education instilled in the students some wrong learning ideas, and this learning concept make them pay too much attention to the final test scores rather than what they learn, so the contemporary students have develop a utilitarian learning habits. Because of the misleading guidance of long-term examination-oriented education, most students do not realize the benefits of entrepreneurship education for their future sustainable development, and they do not know what the content of entrepreneurship education is, whether it can really solve their career and employment and the series of problems. The following article makes a detailed analysis of this problem for your reference.

\section{Review of Research Status}

\section{(1) The emergence and development of entrepreneurship education}

The concept of entrepreneurship education was first developed from abroad. So far, it has a profound history of development. Therefore, the development of entrepreneurship education in developed countries is very solid. In late twentieth century, with the rapid transformation and development of the times, some advanced educators are aware that the traditional closed teaching model has been unable to meet the needs of today's society for talent, so entrepreneurial education model has to be adopted to fully stimulate the students' potential creative ability. More than 20 years later, the United Nations Department of education has begun to attach importance to this problem, giving many policy support and encouragement, and providing a good environment for the continuous development of entrepreneurship education. However, the development of entrepreneurship education in China is relatively backward. So far, there are still a series of problems that will hinder the sustainable development of the reform process.

(2) It is necessary to combine ideological and political education with entrepreneurship education.

Nowadays, college students are the hope of the nation and the future of the country, shouldering the responsibility of history. And this period is also important for their life development and critical to form the correct views of consciousness. If the university does not correctly educate or guide their ideology or help the students to establish the correct world outlook, outlook on life and values to strengthen their self-cultivation, it will inevitably have a negative impact on the development of 
entrepreneurship education. Therefore, ideological and political education is the fundamental guarantee for the development of entrepreneurship education. From another point of view, entrepreneurship education is a further extension of ideological and political education, after the correct understanding of society, others and themself, students begin to improve their own quality through entrepreneurial education to break the past conservative thinking model and master new learning methods and techniques and exercise their own creative thinking. All in all, there is an interdependent and irreplaceable relationship between the ideological and political education with entrepreneurship education.

\section{Significance and Value of Research}

\section{(1) Ideological and political education and entrepreneurship education are same in the nature of education}

Although there are some differences in the content between the two educations, their goals are consistent. The two have always adhered to the principle of "student-centered", as far as possible to stimulate the initiative and creativity of students, and constantly improve their quality to meet the fierce social competition. Being the future pillar of the state and the elite from all walks of life, students should not only have a certain occupation moral quality, but also continue to improve and develop their own innovation ability, both of which must be promoted in ideological and political education and entrepreneurship education, so as to lay a good foundation for future work.

(2) Ideological and political education and entrepreneurship education are integrated in the content of education.

Nowadays, students should have higher quality and ability, so students should not only strive to improve their scientific and cultural level and professional ability, but also improve their ideological and moral qualities at the university stage. Only effective combination can make students invincible in the future fierce social competition. What should be paid special attention to is that the teaching contents of both are interlinked. Specifically, both of them aim to regulate the behavior of students. Although there are some difference in the function in regulating the field, the way and the goal, they are important means to enhance the students' comprehensive quality. Of course, in the practical teaching process, we can not clearly separate the two education, but often consciously instill one kind of education ideology in another education, and encourage students to discover new problems, form new ideas, and try new methods.

(3) Ideological and political education and entrepreneurship education are connected in the function of education.

Ideological and political education is the education for college students in life value, moral cultivation and other aspects, to guide students to establish the correct principle of doing things, and constantly improve their ideological and moral quality. Entrepreneurship education is to help the students learn the knowledge of scientific and cultural theory, master the basic survival and practical ability, deepen their understanding of the ideological and moral in the process, so as to be able to combine the knowledge with action organically. It is said that "virtue is the foundation of the people and talent is the base of the people", which is a good explanation of the importance of the two education for students' development. Only straightening out the relationship between good morals and talents can students achieve all-round development.

\section{Innovation Strategy of Mechanism}

Thinking of teaching reform of ideological and political course in higher vocational colleges under the background of entrepreneurship education. Ideological and political education and entrepreneurship education play an immeasurable role in training students' basic research and application research ability. Although the two education reform gradually is attached importance in our country, it has a series of problems in the teaching process, such as rigid and single teaching mode, boring content and poor operability, hindering the improvement of teaching level. To solve 
this problem, relevant department of education has carried out teaching reform. The following introduces some experience in teaching reform.

\section{(1) Change the teacher's educational concept of ideological and political course}

In the teaching process, the leading role of the teachers is the fundamental guarantee to realize students' subjectivity, so teachers must adhere to the principle of students-centered, fully aware of their role, and play role well to overcome the bad habits of relying on teachers for everything, and provide a platform for independent learning. For example, when the classroom atmosphere is relatively rigid, the teacher should actively encourage students to express their opinions, not directly give the answer, summarize the students' views after some discuss, and then point out the advantages and shortcomings, so students can do better in the feature. Due to the requirement of teaching reform that ideological and political education and entrepreneurship education should be carried out at the same time, so the teachers should work hard, constantly enrich their own ideological and moral qualities and improve professional teaching ability to lay a solid foundation for the development of the students. In addition, teachers should constantly adjust their teaching plan according to the pace of reform, and always keep pace with the times. At the same time, teachers and students to establish a new teacher-student relationship to respect each other, and give full play to their personal charm to attract the attention of students in the classroom.

\section{(2) Adjust the teaching content of ideological and political course}

In the ideological and political education, teachers should extract and grasp the outstanding thought achievement our ancestors left us, add new knowledge combining with the characteristics of the times, so as to enrich the teaching content of the ideological and political education, strengthen students' moral cultivation. Only on such basis, students can learn other scientific and cultural knowledge extensively. In this process, we must take into account the link between original ideological and moral knowledge and the new knowledge for students to build a reasonable framework of knowledge structure, so students can timely know latest achievements and academic trends about various disciplines, and put new knowledge in a wide range of backgrounds. In addition to the theoretical knowledge, colleges also add some practice, which reflects the practicalness of the ideological and political course, adhering to the theory of learning with practice, constantly adjusting the teaching content of ideological and political class, so as to adapt to the development of modern learning needs.

\section{(3) Reform the teaching methods and means of ideological and political course}

In the teaching process, teaching means will have great effect on the students learning enthusiasm, initiative and creativity, so the teachers should adopt flexible teaching methods to stimulate students' interest in learning. In the traditional teaching mode, the teacher just spread the book knowledge blindly, so now we have to make some attempt for the reform in teaching. Teachers should inspire students as much as possible to find life and guide the students themselves to fully understand, grasp and apply the knowledge. In this way, students can gradually master the basic theory and corresponding methods, and realize the true meaning of the basic principles, and accumulate rich practical experience for the future work. In addition, the new teaching media has been further extended, and the traditional learning method based on books has not been able to meet the learning needs of students, so teachers should learn to use modern educational information resources.

Many people have some misunderstandings about ideological and political education. They think only by giving students a certain theoretical knowledge could realize the purpose of teaching which is completely wrong. At present, most schools have ideological and moral education, but only stay on the concept and form, and did not play its role. The basic reason is the lack of relevant practice exercise, and it does not make the students realize the importance of ideological and moral quality for their development. Moreover, many teachers adopt a single form of teaching, which greatly reduces the students' enthusiasm for learning. Therefore, on the one hand, we should change the traditional theory of the wrong teaching form of emphasizing theory and neglecting practice, which is the prerequisite for students to be able to use what they learn. On the other hand, the entrepreneurship education asks teachers to adopt enlightening ideas and methods in the teaching 
process, rather than follow the beaten track to cultivate the bookworm who could not meet the requirements of the social development.

Actually, all education need the school to provide the good platform for the student development, we must guarantee the teacher's guidance status as far as possible and adhere to the student-oriented principle in this platform, which could not only satisfy the freedom and flexibility of students' independent learning, but also stimulate curiosity through the coalition of college and enterprise and gain experience in practice and accumulate rich practical experience for future development.

\section{Conclusion}

Through the above elaboration, I believe readers have a general understanding about the relationship between entrepreneurship education and ideological and political education, at the same time, have a basic understanding about relevant measures of how to improve the quality of teaching reform. The teaching experience in the past few years shows that the reform of the teaching mode has achieved good teaching results. Through this model, students derive a wealth of spiritual nutrition, so that they can apply what they have learned. The colleges are also aware of the important goal of teaching, which is cultivating students into talents of all-round development. Education reform must be continuously optimized and improved on the aspects of content, method and form of teaching according to the feedback of actual situation, which can really adapt to the development of education and the needs of the students' comprehensive ability.

\section{References}

[1] Zhang Xia. Research on Entrepreneurship Education Model of Agriculture Related Majors in Higher Vocational Education -- Taking Horticultural Technology Specialty as an Example [J].Journal of Anhui Agriculture Sciences, 2016, 44(20): 245-247

[2] Lv Herong, Sun Fengqin. Reform and Practice of Training Courses in Higher Vocational Colleges under the Guidance of Innovation and Entrepreneurship Education [J]. Education and Vocation, 2014, (14): 156-157

[3] Wang Tao. Exploration of Innovation and Entrepreneurship Education Model in Higher Vocational Colleges -- Taking Chengdu Institute of Entrepreneurship as an Example [J]. Vocational and Technical Education,2015, (2): 53-56

[4] Xiang Li. Teaching Reform of Ideological and Political Courses in Higher Vocational Colleges Oriented to Entrepreneurship Education [J]. Innovation and Entrepreneurship Education, 2014, (3): 61-62

[5] Innovation entrepreneurship education [J]. Journal of Beijing jiaotong university (social science edition); 2011 (3) : 15.

[6] liu yanwen, both liping. On the impact of the Beijing industrial restructuring on education in higher vocational colleges [J]; Journal of the joint university of Beijing; 2012 (01) : 33-36.

[7], in the spring. The sustainable development of higher vocational students ability training mode study [J];Journal of chongqing industry and trade professional technology institute;2011, 03.

[8]. The concept of education. Journal of the changsha aviation vocational and technical college; 2002 (04) : 12-13.

[9] li wen-hong. Research on key ability of graduates in higher vocational colleges [J]; Journal of the taiyuan urban vocational and technical college; 2010 (08) : 35-38.

[10] The path choice of "moral education and legal foundation" in higher vocational colleges [J]; High education BBS; 2010 (6) : 25-26. 